\author{
Nuclear non-proliferation's moment has come. Scientists must help governments to seize a historic \\ opportunity to avoid future apocalypses.
}

W

hen leaders of the G20 nations gather in London this week, their attention will undoubtedly be focused on the current financial crisis. But it cannot be their exclusive focus: the crisis itself is a grim reminder that imminent global threats are best dealt with before the event, not after. And nothing poses a greater threat for creating further crises than nuclear weapons, either in existing stockpiles or through their acquisition by an increasing number of states - or by terrorists.

Fortunately, many of the G20 attendees seem to feel that urgency. Their host, UK prime minister Gordon Brown, has signalled that he is ready to put cuts to his country's arsenal on the table - although his government remains committed to a costly revamp of its deterrents, despite a lack of compelling justification. And US president Barack Obama and his Russian counterpart Dmitry Medvedev are expected to sign a pledge at the G20 meeting to reach an agreement by the end of the year to make substantial cuts to their nuclear arsenals.

This is excellent news, especially given how relations between the United States and Russia have soured over the past decade. The two countries first agreed to large reductions in their nuclear stockpiles under the Strategic Arms Reduction Treaty, which was formulated in 1982 and finally signed in 1991. But that treaty expires in December, and as yet no follow-up has been pursued. A new nuclear entente is sorely needed - not least to tackle the terrorist threat posed by the insecure stockpiles of weapons and fuel across the countries of the former Soviet Union.

But the world's leaders need to go much further. Over the past decade the whole fabric of the nuclear non-proliferation regime has begun to unravel - notably through the failure to implement ways to strengthen the Nuclear Non-Proliferation Treaty, such as through a Comprehensive Nuclear Test Ban Treaty. The situation is now dire. North Korea, which tested a nuclear device in 2006, seems set to test an intercontinental ballistic missile within days. Pakistan, which is estimated to have dozens of nuclear warheads, is politically unstable. And Iran, according to many scientists, now has enough fuel-grade low-enriched uranium to convert into a bomb's worth of highly enriched uranium, should it choose to do so.

These challenges will only grow more acute if, as expected, nuclear power is revived around the world as a way to mitigate climate change. A solution is urgently needed to ensure that the fuel intended for civilian nuclear reactors, as well as the huge amount of waste they produce, is not diverted to military ends. Some radical solutions are already under discussion, such as bringing all fuel-production facilities under multinational control.

Forging a consensus on these matters will not be easy. But scientists and engineers can play a crucial part by redoubling their efforts to create informal scientific and diplomatic backchannels. Particularly notable in that context is a conference taking place on 17-20 April in the Hague: the 58th annual meeting of the international Pugwash movement (see page 575). The movement's frequent convocations of influential scientists, politicians and other figures are credited with making key progress in arms control during the cold war. And although today's geopolitics are very different, the movement's efforts are as relevant as ever. Behind the scenes, for example, Pugwash is pursuing informal contacts with Iran to find ways out of that crisis. Scientists are also engaging in disarmament in newer organizations such as the non-profit US Nuclear Threat Initiative, which is working to reduce nuclear threats by championing a multilateral fuel bank, and a clean-up of stocks of highly enriched uranium.

Indeed, there is cause for optimism on the nuclear front. Obama's pledge to work towards a world free of nuclear weapons seems sincere, and is galvanizing support for new multilateral efforts in nonproliferation. With quick action, moreover, there is still time to build enough political momentum and preparation to make substantial progress at next year's crucial review conference of the Nuclear NonProliferation Treaty. The United States could send a strong signal here by sending the Comprehensive Test Ban Treaty to the Senate for ratification - as Obama has said he intends to do. As Brown said in a landmark speech on the topic on 17 March, it is time "to transform the discussion of nuclear disarmament from one of platitudes to one of hard commitments".

\section{Clicking on a new chapter}

\section{The e-textbook is only one part of a bigger revolution in online learning.}

or generations, students have flipped through their textbooks to amplify or clarify what they have heard in their lectures, to remind themselves how the various ideas relate one another, and - especially important in science courses - to find a good graphical depiction of the ideas they are struggling to understand. Once a student can picture in his or her mind the structure of DNA, say, or the mechanism of the greenhouse effect, much of the teacher's job is done.

Students will always need this kind of help; it is central to the learning process. But they might not be getting it from a printed textbook for much longer. The boundaries of the textbook have been stretching for some time now. Many already come with a CD attached, or include access to a website where updates and supplementary information can be found. Now those boundaries are threatening to burst entirely, as publishers experiment with making their textbooks available on personal computers, e-readers such as 